\title{
Challenges faced by the clothing sector in Zimbabwe
}

\author{
Tongesai Mpofu', \\ ${ }^{I}$ (Department of International Marketing, Chinhoyi University of Technology, Zimbabwe
}

\begin{abstract}
The aim of this paper was to highlight the major challenges faced by clothing companies in Zimbabwe. The rise came as a result of the outcry from clothing companies in Zimbabwe. Firms in the clothing sector rely on imported fabric for production in order for them to better service its customers. The paper looks at challenges and how they are affecting operations.

This is a conceptual paper and the methodology used is a desktop research and an in depth interview with the clothing sector chairman. The findings of the paper confirms that the major challenges in the sector were cheap imported clothing from Asia and second hand clothing coming through charity organisations.

The study concludes that local companies need to consider buying from local clothing manufacturing firms before making importation decisions. The government needs to implement measures to protect the local industry as it is a major source of employment.
\end{abstract}

Keywords: challenges, clothing sector, dumping, fabric, threats, imported, second hand clothing

\section{INTRODUCTION}

The clothing sector plays an extremely significant role in Zimbabwe in terms of employment, share in value addition, foreign exchange earnings and contribution to Gross Domestic Product (GDP). Kanyenze (2006) says that the clothing and textile sectors play a major economic role in many developing countries especially in Africa and Asia. For many countries the textile and clothing sectors provide one of the first stages of economic upgrading or diversification away from a dependency on primary commodities and it has significant forward and backward linkages. The sector provides vital commodities that no country can do without such as shirts, trousers, suits, dresses, hats, stockings and underwear, blankets, towels. In support Nkala (2010) says that the clothing sub-sector has played and continues to play a major role in the Zimbabwean economy. The industry has gone through a ten negative growth since the year 2000 with many mills and factory closure, more than 11000 job losses were recorded, mostly due to harsh economic conditions and poor implementation of critical marketing success factors, the traditional marketing mix (product, price, promotion and place) Youmans (2011).

TABLE 1.I Number of firms and employment in the clothing industry

\begin{tabular}{|l|l|l|}
\hline Year & Number of Companies & Number of people employed \\
\hline 2000 & 495 & 20000 \\
\hline 2008 & 395 & 12000 \\
\hline 2011 & 296 & 9000 \\
\hline
\end{tabular}

Source: Zimbabwe Clothing sector database (January 2011)

According to the Zimbabwe Clothing Association (2011), in 2000 there were 495 clothing companies and the sector employed 20000 people. By 2008, a total of approximately 111 firms in the clothing sector shut down representing 44\% shrinkage of the respective sector and employment declined to 12000 . In January 2011 the companies declined to 296 and employment to 9000 (Zimbabwe Clothing Association 2011, Mpofu 2011). This shows that this sector is important for employment creation as it is labour intensive hence the need for its revival.

\section{Problem STATEMENT}

Despite the contribution of the clothing sector to national employment and GDP it faces serious closure and has not received much attention from policy makers. The following question can be posed, "how can this sector be strengthened" or what is the way forward?

\section{Challenges FaCEd By The Clothing SeCtor}

The revival of the clothing manufacturing sector continues to face serious challenges as the importation of duty-free finished clothing continues. Players in the sector have consistently complained that Zimbabwe has become a dumping ground of low quality and cheap goods threatening the livelihoods of thousands of people. The clothing sector is facing challenges like closure of companies which are threatening its survival (Muzariri 
2010 and Youmans 2011). The Government has been called upon to invoke statutes of the World Trade Organization to help protect the local industry (Wednesday, Herald 28 April 2010). Former chairman of the Clothing Manufacturers Association of Zimbabwe Muzariri said that the problems faced by the sector were diverse. Youmans (2011) noted that most companies are operating below capacity around $40 \%$ except a few which are operating at $80 \%$ and urged that strategies need to be put in place to improve operations. Government was advised to invoke WTO statutes that a country has got the right to protect itself from the dumping of goods (Herald April 28, 2010). An industrial analyst Guyana (2010) said that the clothing sector was a powerful vehicle for employment creation and added that the sector should get preferential treatment for tenders from Government departments who should consume locally manufactured goods before considering imports. $\mathrm{He}$ urged that the local industry had the capacity to satisfy the local market demand on supply and quality but could only be revived if or when the country stops de-industrializing itself through rejecting being a dumping ground (Herald 20, April 2010).

In support of this the chairman of the clothing sector in Zimbabwe said that the major challenges faced by the sector include the influx of cheap imported clothing from China, a lot of second hand clothes that was being sold in open spaces like Mupedzanhamo in Mbare as this lowers demand for locally produced clothing. The sector also has high wage bills of US $\$ 110$ which was higher when compared to Malawi which paid US\$35, Mozambique US\$45. The serious challenge was that of closure if the wage bill were to be raised to US\$147 which was being advocated by the arbitration then. To add on that, the other challenge was that of transshipment of clothes from China through Tanzania enjoying preferential treatment due to fake rules of origin. Another challenge was that of corruption at border post, where ZIMRA officials were being bribed to let second hand clothes into the Zimbabwean market and also other invoices were undervalued resulting in less duty being paid (Clothing Chairman).

The Zimbabwean clothing sector is fast losing its domestic market share forcing companies in the sector to close, downsize its labour force, reduce production capacity. Companies are not only failing to maintain the local market share but also the international market share for those that were involved in export business. The research on clothing under the auspices of the World Bank (2006) further observed that, 'another huge problem is second hand and even illegal imports. According to a rough estimate about $40 \%$ of the total clothing consumption in Zimbabwe is second hand clothing, being charity imports from Malawi, Mozambique and Zambia. Results from the 2000 survey confirmed the continued growth of this sector at the costly expense of the rest of the industry. Of growing concern in the clothing sector, especially among the smaller companies, is the continuous growth in the second hand clothing market and illegal imports from within the SADC region (Kanyenze, 2006). The past economic recession also affected the clothing sector which was characterized by hyperinflation. Political stability also affected relations of the companies since most fabric is imported. It is against this background that the researcher investigated how local companies can regain their market share on the local market.

\section{CONCLUSION AND RECOMMENDATIONS}

The sector is facing many challenges which include raw material sourcing since there are no local suppliers of fabric, high wage bills, second hand and cheap imported clothing and illegal imports. The clothing sector forms a major part of the manufacturing production, employment and trade in Zimbabwe and hence it need to be reinvigorated so that it can survive now and into the future.

In order for the companies to achieve competitiveness the study recommends that the need to limit second hand clothing as second hand clothing has increased dramatically since 1994 and this has created an urgent need for a comprehensive policy on dealing with these imports.

For competitiveness to be achieved in the Zimbabwean clothing there is need for infrastructure development that would help reduce production cost and improves quality.

The other recommendation is to improve trade relations with South Africa so that Zimbabwean companies import textile from South African textile companies. This will in turn reduce transportation costs as well as inventory costs as the companies do not have to stock lots of fabric (Mpofu 2011).

\section{REFERENCES}

[1] G. Kanyenze, The Clothing and Textile Industry in Zimbabwe, Herbert Jauch / Rudolf Traub-Merz (Eds.), 2006

[2] S. Nkala, Clothing and textile Write Up, Zim Trade, Zimbabwe 2010

[3] J. Youmans, Interview, Clothing Association of Zimbabwe Chairman, Harare, Zimbabwe, 2011

[4] T Mpofu, Evaluation of distribution strategies used to increase sales volume in the Zimbabwean Clothing Sector (2008- 2010), Master diss., Midlands State University, Gweru, Zimbabwe 2011 (unpublished dissertation)

[5] The Herald: Duty free imports continue to batter clothing industry in Zimbabwe, quoting Muzariri and Guyana, April, 2010

[6] World Bank, Zimbabwe: The Capital Goods Sector, Investment and Industrial Issues, Washington, D. C, 2006 